THE PUBLIC INTELLECTUAL AND

THE CULTURE OF HOPE 
This page intentionally left blank 


\section{The Public Intellectual and the Culture of Hope}

EDITED BY

JOEL FAFLAK AND JASON HASLAM

UNIVERSITY OF TORONTO PRESS

Toronto Buffalo London 
(C) University of Toronto Press 2013

Toronto Buffalo London

www.utppublishing.com

Printed in Canada

ISBN 978-1-4426-4184-6

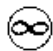

Printed on acid-free, $100 \%$ post-consumer recycled paper with vegetable-based inks.

\section{Library and Archives Canada Cataloguing in Publication}

The public intellectual and the culture of hope / edited by Joel Faflak and Jason Haslam ; foreword by John Polanyi.

Includes bibliographical references and index. ISBN 978-1-4426-4184-6 (bound)

1. Intellectuals - Social conditions. 2. Intellectual life. I. Haslam, Jason W., 1971- II. Faflak, Joel, 1959-

HM728.P82 $2013 \quad$ 305.5’52 C2013-904063-3

This book has been published with the help of a grant from the Canadian Federation for the Humanities and Social Sciences, through the Awards to Scholarly Publications Program, using funds provided by the Social Sciences and Humanities Research Council of Canada.

University of Toronto Press acknowledges the financial assistance to its publishing program of the Canada Council for the Arts and the Ontario Arts Council.

University of Toronto Press acknowledges the financial support of the Government of Canada through the Canada Book Fund for its publishing activities. 